\title{
The Independence Process of Bulgaria and the First Ambassador of the Ottoman Empire to Sofia, Mustafa Asim Bey
}

\begin{abstract}
Abidin Temizer*
Abstract

In this study, the reaction of the Ottoman Empire to the declaration of independence of Bulgaria, the first ambassador of the Ottoman Empire in Bulgaria, Mustafa Asım Bey and his activities are discussed.

The study examines the diplomatic activities of the Ottoman Empire against Bulgaria in the period between the autonomy process of Bulgaria and the independence process, the process of recognition of Bulgaria's independence, the diplomatic relations established with Bulgaria, the biography of Mustafa Asim Bey, the first Ambassador of the Ottoman Empire to Sofia, and his approach to the problems between the two countries.

In the article, documents from the Ottoman Archive of Directorate of State Archives (BOA), documents from the Bulgarian State Archives, periodicals and literature were used.
\end{abstract}

Keywords: Balkans, Independence of Bulgaria, Mustafa Asım Bey, Ottoman-Bulgarian Relations, Sofia Embassy

\section{Bulgaristan’ın Bağımsızlık Süreci ve Osmanlı Devleti’nin Sofya'daki} İlk Sefiri Mustafa Asım Bey

\section{$\ddot{O ̈}_{\mathbf{z}}$}

Bu çalışmada Osmanlı Devleti'nin Bulgaristan'ın bağımsızlık ilanına tepkisi, Osmanlı Devleti'nin Bulgaristan'daki ilk büyükelçisi Mustafa Asım Bey ve faaliyetleri ele alınmıştır.

Çalışma Bulgaristan'ın özerklik süreci ile bağımsızlık süreci arasında geçen süreçte Osmanlı Devleti'nin Bulgaristan'a karşı diplomatik faaliyetlerini, Bulgaristan'ın ba-

* Prof. Dr., Burdur Mehmet Akif Ersoy University, Faculty of Science and Letters, Department of History, Burdur/TURKEY, abitem@gmail.com ORCID: 0000-0001-5708-3132

DOI: $10.37879 /$ belleten.2021.1073

Application date of article: 27.08.2020 - Approval date of article: 02.08.2021

Belleten, Aralık 2021, Cilt: 85/Sayı: 304; 1073-1104 
ğımsılı̆̆̆ının tanınması sürecini, Bulgaristan ile kurulan diplomatik ilişkileri, Osmanlı İmparatorluğu'nun ilk Sofya Büyükelçisi Mustafa Asım Bey’in biyografisini ve iki ülke arasındaki sorunlara yaklaşımını ele almaktadır.

Çalışmada, Bulgaristan’ın özerklik süreci ile bağımsızlık süreci arasındaki dönemde Osmanlı Devleti'nin Bulgaristan'a karşı diplomatik faaliyetleri, Bulgaristan’ın bağımsızlı̆̆ının tanınması süreci, Bulgaristan ile kurulan diplomatik ilişkiler, Osmanlı İmparatorluğu'nun ilk Sofya Büyükelçisi Mustafa Asım Bey’in biyografisi ve iki ülke arasındaki sorunlara yaklaşımı ele alındı.

Çalışmada Devlet Arşivleri Başkanlığı Osmanlı Arşivi (BOA) belgelerinden, Bulgaristan Devlet Arşivleri belgelerinden, süreli yayınlardan ve literatürden yararlanılmıştır.

Anahtar Kelimeler: Balkanlar, Bulgaristan'ın Bağımsızlı̆̆ı, Mustafa Asım Bey, Osmanl-Bulgaristan Ilişskileri, Sofya Sefareti

\section{Introduction}

This study aims to analyze the independence process of Bulgaria, the reactions of the Ottoman Empire throughout this process, and Mustafa Asım Bey, the first Ottoman ambassador assigned to Sofia, and his activities regarding the subject matter. The article is limited to the independence process of Bulgaria and the reactions by the Ottoman Empire after the independence and the first ambassador, Mustafa Asim Bey. It also addresses the reaction of the Ottoman Empire and the actions conducted by the first ambassador.

The study is divided into five parts. In the first part, the establishment of the national consciousness of Bulgaria and the Bulgarian rebellion is discussed. In the second part, Bulgaria's attainment of its autonomy; in the third part, the relationships between the Ottoman Empire and the Bulgarian Princedom throughout the autonomy period are discussed. In the fourth part, the declaration of Bulgaria's independence and the reaction of the Ottoman Empire are examined. And in the fifth part, reciprocal ambassador and consul assignment of the two countries, Mustafa Asim Bey, the first ambassador the Ottoman Empire assigned to Sofia, and his ambassadorship are discussed in detail. In this part, the discussion is devoted to the biography of Mustafa Asim Bey and his assignment process, the Embassy personnel during his Sofia ambassadorship, conversion of Merchant Deputies (Tüccar Vekâleti) into consulates, and the impact of Mustafa Asım Bey on Ottoman-Bulgaria relations throughout this period. In order to ensure the integrity of the article and not to exceed the limitations of the article, only some 
examples of Mustafa Asım Bey's activities in Sofia are given, and not all of his activities in Sofia are mentioned in this part.

In the study, data collection and document analysis methods were used. The relevant documents from the Ottoman Archieve of Directorate of State Archives in Istanbul (BOA), documents from the Bulgarian State Archives, periodicals, and the general literature were used as a resource in the study.

\section{Formation of Bulgarian National Awareness and Rebellions}

The conquests of the Ottoman Empire in Bulgaria started during the reign of Sultan Murat I and were completed with the Battle of Nicopolis in 1396 ${ }^{1}$. The Bulgarians lived under the Ottoman Empire's rule without causing any problems for the Ottoman Empire until the $18^{\text {th }}$ century. While the Bulgarian nation was not recognized until the end of the $18^{\text {th }}$ century ${ }^{2}$, a national Bulgarian identity started to emerge as of the end of the $18^{\text {th }}$ century ${ }^{3}$. Bulgarian Monk Paisii started the first national spark of the Bulgarians with his work "Slavic - Bulgarian History" (Istoriya Slavyanobilgarska) in $1762^{4}$. This development was followed by the uprisings, which started occurring in the first half of the $19^{\text {th }}$ century ${ }^{5}$.

In the $19^{\text {th }}$ century, the pressures of the Fener Greek Orthodox Patriarchate on the Bulgarians and the weakening of the Ottoman military and economic power were

1 Ayșe Kayapınar, "Bulgaristan'da Osmanlı Hâkimiyetinin Kurulması: Dönemlendirme Sorunu ve İskân", Türk Tarihinde Balkanlar, Sakarya 2013, pp. 319-320; M. Tayyib Gökbilgin, Rumeli'de Yürükler, Tatarlar ve Evlâd-ı Fâtihân, İstanbul Üniversitesi Edebiyat Fakültesi Yayınları, İstanbul 1957, p.13; Halil İnalcık, Osmanl İmparatorluğu Klâsik Çağ (1300-1600), YKY, İstanbul 2003, pp. 22; Mehmet İnbaşı "XVI-XVII. Yüzyllarda Bulgaristan'daki Yörük Yerleşmeleri”, Uluslararası Osmanh ve Cumhuriyet Dönemi Türk Bulgar Illiskileri Sempozyumu, Bildiriler Kitabı, May1s 2005, pp. 174183. p. 397.

2 Halil İnalcık, Tanzimat ve Bulgar Meselesi, Eren Yayınları, İstanbul 1992, p. 17.

3 Evguenia Davidova, "A Centre in the Periphery: Merchants during the Ottoman period in Modern Bulgarian Historiography (1890s - 1990s)", Fournal of European Economic History, 31/3, 2002, p.665. About development of Bulgarian nationalism see Fatma Rodoplu Ylldırım, "Bulgar Milli Uyanışı Ve Bulgar Milliyetçiliğinin Özellikleri”, Milliyetçilik Araşırmalan Dergisi, 2/ 1, 2020, p. 96-99.

4 Tzaneva, Elya, Ethnosymbolism and the Dynamics of Identity, Cambridge Scholars Publishing, 2015, p.139.; Olga Borysova; Nikolai Karpitsky, "Father Paisii Hilendarski`s Message About the Volga Ancestral Home of the Bulgarians as a Source of Formation of National Historical Consciousness", Fournal of International Eastern European Studies, 1/2, Winter, 2019, p. 249; Rodoplu Yildırım, "Ibid"., p. 98.

5 Inalcık, Tanzimat ve..., p. 26. 
effective in the development of Bulgarian nationalism ${ }^{6}$. The idea of nationalism of the 1789 French Revolution and the Panslavist policy of the Russians also led to the development of Bulgarian nationalism in Bulgaria ${ }^{7}$. The first severe rebellions of the Bulgarians against the Ottoman Empire were the revolts launched in Vidin in 1841, 1849, 1850, and 1860 because of heavy taxation and a claim of ill-treatment of Bulgarians ${ }^{8}$. Rebellion committees were established in the region as of 1860. Bulgarian committees were based in Wallachia and Moldavia (Eflak and Boğdan) for strategic reasons as they could move around more freely from there ${ }^{9}$.

Firstly Bulgarian clergy house and then on March 11, 1870, the independent Bulgarian Church was established, as a result of the pressure of the Greek Church on the Bulgarians, the development of the Bulgarian nationalism, and the effects of the Tanzimat Fermani (The Gülhane Edict) ${ }^{10}$.

The Bulgarians, who continued to rebel after the establishment of the Bulgarian Church, made significant rebellions in 1870 and $1876^{11}$. As a result of the rebellions in the Balkans, the Istanbul Conference was held on December 23, 1876, with the participation of some states that had signed the Paris Treaty of 1856, Russia, Great Britain, France, Austria-Hungary, Germany and Italy ${ }^{12}$. As

6 Richard J. Crampton, Bulgaria, Oxford University Press, 2007, p. 24-25.

7 Michael Boro Petrovich, The Emergence of Russian Panslavism 1856-1870, Columbia University Press, New York 1958, p. 130-139; Hans Kohn, Pan-Slavism-Its History and Ideology, University of Notre Dame Press, Indiana 1953, p. 157-160, 323; Erhan Vatansaver, Bulgar Milliyetçiliğinin Doğuşu ve Bulgaristan’n Bağımsızlı̆̆ı (1841-1908), (Unpublished Ph.D. Thesis), Trakya University, Intitute of Social Sciences Department of History, Edirne 2019, pp. 39-49.

8 Crampton, Ibid., p. 24-32; Yusuf Halaçoğlu, "Bulgaristan (Osmanlı Dönemi)", TDV İslâm Ansiklopedisi, 6, İstanbul 1992, p.397.

9 Mithat Aydın, "Bükreş'te Komitacılık Faaliyetleri (1860-1916)", Fournal of Modern Turkish History Studies, XV/30 (2015-Spring), p.8-9; Tamer Balc1, "Ottoman Balkan Heritage and The Construction of Turkish National Identity”, Osmanh Mirası Araştrmalar Dergisi, 1/1, November 2014, p.64.

10 Ramazan Erhan Güllü, "Bulgar Eksarhlığı’nın Kuruluşu ve Statüsü”, Gaziantep University fournal of Social Sciences, 17/1, 2018, p.350-355; Canan Seyfeli, "Osmanlı Devlet Salnamelerinde Bulgar Eksarhlığı ve Bulgar Katolikler (1847- 1918)", Ankara Üniversitesi İlahiyat Fakültesi Dergisi, 52/2, 2011, p.166; Nuri Korkmaz, "Bulgar Milliyetçiliğinin Doğuşu, Ortodoks Unsurları, Gelişimi ve Türklerin Ötekileştirilmesi”, Gazi Akademik Bakış, 20/20, 2017, p. 74-75.

11 Mithat Aydın, Balkanlar'da İsyan, Yeditepe Yayınevi, İstanbul 2005, p.150-152; Halaçoğlu, "Ibid." p.397; Pinar Üre, "Immediate Effects of the 1877-1878 Russo-Ottoman War on the Muslims of Bulgaria”, History Studies, Fournal of the University of Limerick History Society, V.13, 2012, p. 158.

12 Enver Ziya Karal, Osmanh Tarihi, VIII, TTK, Ankara 1988, p.28; Zafer Gölen, "Osmanlı Yurdu 
a result of the conference, the Great Powers made demands from the Ottoman Empire. Their demand for Bulgaria was to divide Bulgaria into two provinces as east and west. An international commission was created to oversee the reforms and five thousand Belgian soldiers were assigned to protect this commission ${ }^{13}$. The Ottoman Empire's refusal to accept reform demands became an excuse for the 1877-1878 Ottoman-Russian war and Russia took action by declaring war on the Ottoman Empire ${ }^{14}$.

\section{Bulgaria Gaining Autonomy}

The most critical development that paved the way for Bulgarian independence was the 1877-1878 Ottoman-Russian war. Although the independent Bulgaria was established with the Treaty of San Stefano, which was signed after the success of the Russian army that had advanced up to San Stefano (Yeşilköy) in this war, the 1878 Berlin Conference changed this situation. As a result of the Berlin Conference, the territory of Bulgaria was divided into three regions, with the Berlin Treaty signed on July 13, 1878. The first region was a Bulgarian Principality, which was subject to the Ottoman Empire, was free in its internal affairs, the prince of which was chosen by the people and appointed with the approval of the Sublime Porte (Bâbiâli) and the Great Powers, where Ottoman soldiers were not deployed and the area of which was shrunk ${ }^{15}$. The principality, whose capital was Sofia, was to be taxed by the Ottoman Empire ${ }^{16}$. The second region, which was administratively independent but subject to the Ottoman Empire politically and militarily and was administered by a Christian governor appointed for 5 years by the Sublime Porte with the approval of the European states, was Eastern Rumelia Province (Şarki Rumeli Vilâyeti) ${ }^{17}$. The third region was Macedonia ${ }^{18}$.

Olan Bosna-Hersek’te XIX. Yüzylldaki Siyasi Olaylar“, Belleten, LXXIV/270, August 2010, p. 460; Zafer Gölen, "Karadağ Devletinin Doğuşunda Büyük Güçlerin Rolü (1850-1875)“", Almanah, 63-64, Podgorica 2014, p. 184.

13 Mithat Aydın, "Osmanl-İngiliz İlişkilerinde İstanbul Konferansı (1876)'nın Yeri”, Ankara Üniversitesi Dil ve Tarih-Coğrafya Fakültesi Tarih Bölümü Tarih Araştrrmalan Dergisi, 25/39, 2006, p. 103.

14 David Schimmelpenninck van der Oye, "Russo-Turkish War (1877-1878)", The Encyclopedia of War, Ed. Gordon Martel, 2011, p. 1.

15 Ali İhsan Gencer, "Berlin Antlaşması", TDV İslâm Ansiklopedisi, 5, İstanbul 1992, p. 517.

16 Caner Sancaktar, "Balkanlar'da Osmanlı Hakimiyeti ve Siyasal Mirası”, Ege Stratejik Araşttrmalar Dergisi, 2/2, 2011 , p. 33.

17 Mahir Aydın, Şarkî Rumeli Vilâyeti, TTK, Ankara 1992, pp. 11-19;

18 Sancaktar, "Ibid.", p. 33. 


\section{Ottoman Empire-Bulgarian Principality Relations in the Period of Autonomy (1878-1908)}

1878-1908 Ottoman-Bulgarian relations developed based on the intervention of the Great Powers and events related to this, the problems of the Muslims in Bulgaria arising from the Bulgarian administration ${ }^{19}$, especially the problems regarding real estate and land and foundation properties of Muslims staying in or migrating from Bulgaria, the occupation of the province of Eastern Rumelia by Bulgaria, and the Macedonian Question ${ }^{20}$.

Bulgaria gained autonomy with the 1878 Treaty of Berlin. After this treaty, Bulgaria was represented by Kapi Kethudaligi in Istanbul ${ }^{21}$, while the Ottoman Empire was represented by the Commissioners (Komiser) appointed to Bulgaria as mandated by the Berlin Treaty ${ }^{22}$. Pertev Efendi, the first Commissioner of the Ottoman Empire, was appointed in September 1878. The names and terms of office of the Commissioners who served in Sofia from 1878 until the independence are shown in the table below:

19 Ali Eminov, "Social Construction of Identities: Pomaks in Bulgaria", fEMIE, 6/2, 2007, p.2; Michael B. Bishku, "Turkish-Bulgarian Relations: From Conflict and Distrust to Cooperation", Mediterranean Quarterly, 14/2, Spring 2003, p. 77.

20 Emine Bayraktarova, Osmanl Devleti-Bulgaristan Prensliği İlişkileri (1878-1908), (Unpublished Ph.D. Thesis), Marmara University, Institute of Turkic Studies), İstanbul 2002, p. 31-41; Meltem Begüm Saatçi, "II. Meşrutiyet Öncesi Makedonya Sorununda "Bulgar" Rolü”, Uluslararası Osmanlı ve Cumhuriyet Dönemi Türk Bulgar İliskileri Sempozyumu, 11-13 Mayı 2005 Eskişehir-Türkive Bildiriler Kitab1, Mayıs 2005, p. 121-124; İbrahim Serbestoğlu, Osmanh Kimdir? Osmanh Devleti’nde Tabiiyet Sorunu, Yeditepe Yayınevi, İstanbul 2014, p. 340-346.

21 BOA. HR.ŞFR.04, 337/124, date: 03-04-1889

22 Mahir Aydın, "Bulgaristan Komiserliği", Belgeler, Türk Tarih Belgeleri Dergisi, XVIII/21, TTK, Ankara 1997, p. 73; Erol Çetin, Bulgaristan Prensliği ve Osmanh Imparatorluğu Arasinda Siyasi İlişkiler (1878-1908), (Unpublished Ph.D. Thesis), İstanbul University, Istanbul 2003, p. 48-49. 
Table 1: Commissioners of the Ottoman Empire in Bulgaria

\begin{tabular}{|c|c|}
\hline Commissioner & Term of Office \\
\hline Pertev Efendi ${ }^{23}$ & September 1878 - December 1878 \\
\hline Nihad Pasha (de Blinski ${ }^{24}$ ) & December 20, 1879 - November 28, 1885 \\
\hline Nikola Gazban Efendi ${ }^{25}$ & December 3, 1885 - March 1887 \\
\hline Huseyin Riza Pasha ${ }^{26}$ & March 1887-February 1888 \\
\hline Kazim Bey ${ }^{27}$ & February 1888 \\
\hline Mustafa Resid Bey ${ }^{28}$ & $1888-1893$ \\
\hline Nebil Bey ${ }^{29}$ & $1893-1895$ \\
\hline Niyazi Bey ${ }^{30}$ & 1895 - November 1897 \\
\hline Abdulhalik Nasuhi Bey ${ }^{31}$ & May 1897 - September 1898 \\
\hline Necib Melhame Bey ${ }^{32}$ & September 1, 1898 - January 20, 1902 \\
\hline Ali Ferruh Bey ${ }^{33}$ & February 4, 1902 - October 20, 1904 \\
\hline Sadik Pasha ${ }^{34}$ & October 27, 1904 - August 1908 \\
\hline Mustafa Sekib Bey ${ }^{35}$ & August 1908 - June 1909 \\
\hline
\end{tabular}

23 BOA. DH.SAIDd, 3/264, date: 29-12-1243 (hijri).

24 Mahir Aydın, "Bulgaristan..”, pp. 76-77.

25 Mahir Aydın, "Bulgaristan..", p. 77.

26 Sinan Kuneralp, Son Dönem Osmanlı Erkan ve Ricali (1839-1922), ISIS Yayınları, İstanbul 1991, p. 47.

27 The appointment of Kazim Bey as Commissioner was not well received by Russia, so his duty was soon terminated. BOA. I.MTZ.(04), 13/774, date: 21-05-1305 (hijri).

28 He performed the duty by proxy. BOA. A.\}MTZ. (04), 23/64, date: 04-03-1309 (hijri). It has not been established when exactly he was appointed. However, it is known that he was in office between 1888-1893. BOA. HR.ŞFR.04.,441/10, date: 06-10-1888; BOA. HR.ŞFR.04, 291/23, date: 16-08-1893.

29 It has not been established when exactly he was appointed. However, it is known that he was in office between 1888-1893. BOA. HR.UHM. 11/19, date: 09-06-1893; BOA. A.\}MTZ. (04), 29/22, date: 06-02-1313 (hijri).

30 BOA., HR.SFR.04., 498/8, date: 15-11-1895; Mahir Aydın, “Bulgaristan..”, p. 78-79.

31 Mahir Aydın, "Bulgaristan..”, p. 79-80; Kuneralp, p. 47.

32 Mahir Aydın, "Bulgaristan..”, p. 80-82.

33 Mahir Aydın, "Bulgaristan..", p. 82-84.

34 Kuneralp, Ibid., p. 47.

35 Kuneralp, Ibid., p. 47. 
The official duty of the commissioner appointed to Sofia was to seek the rights of foundations and Muslim individuals in Bulgaria, such as real estate, land, and inheritance, and to contact the Bulgarian Foreign Service for legal proceedings ${ }^{36}$. However, his primary responsibility was to closely monitor Sofia, Plovdiv, and other cities and the Bulgarian Government ${ }^{37}$.

Another Ottoman Empire representative office founded in Bulgaria was the Traders' Representative. Officers titled Merchant Deputies were sent to Vidin, Varna, Ruse (Rusçuk), Birgoz, Plovdiv (Filibe), and Sofia. Similarly, Bulgaria appointed merchant deputies to Skopje (Üsküp), Salonica (Thessaloniki/Selanik), Bitola (Manastır), Edirne, and Serres ${ }^{38}$.

Although Bulgaria was a Principality affiliated with the Ottoman Empire, in practice, this situation remained on paper and the Bulgarian Prince acted as the leader of an independent country like Greece, Serbia, Romania, or Montenegro ${ }^{39}$. He was received as such in the international arena. The most concrete evidence of this was the welcoming of the Prince of Bulgaria, Ferdinand I, by the Emperor of Austria-Hungary, Franz Joseph I, as an independent ruler in Budapest. In addition, the Bulgarian Government minted its own money from 1880 onwards and the Turkish ${ }^{40}$ lost its status as official language. For all these reasons, the Bulgarian Government regarded the Commissioner appointed by the Ottoman Empire as the Foundations Commissioner who only dealt with the Turkish foundations ${ }^{41}$. Eskişehir - Türkiye Bildiriler Kitabı, Mayıs 2005, p. 292.

41 Mahir Aydın, "Bulgaristan..”, p. 73; Hasan Ünal, "Ottoman Policy during the Bulgarian Independence Crisis, 1908-9: Ottoman Empire and Bulgaria at the Outset of the Young Turk Revolution". Middle Eastern Studies, 34/4, 1998, p. 142-143. 


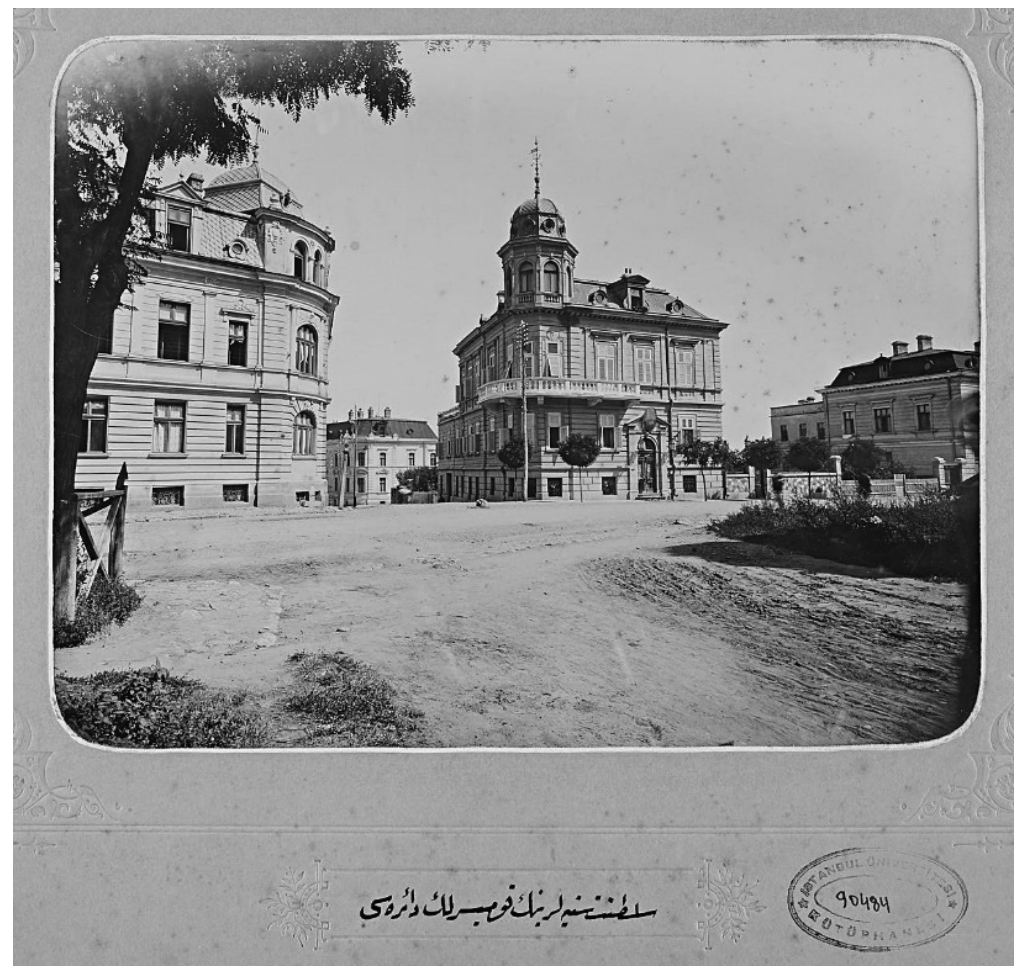

Photo 1: Dining Room of the Sofia Commissioner of the Ottoman Empire ${ }^{42}$

An essential issue of Ottoman - Bulgarian relations during the autonomy period was Bulgaria's Muslim population and their problems. The Muslim population in Bulgaria was equal in number to the Christian population when the 1877-1878 Ottoman-Russian War began. And this affected Russia's policy on Muslims. The Russian army, which entered the Bulgarian territory during the war and the Bulgarian Government, forced Muslims to migrate, adopting inhumane strategies such as massacring, which resulted in tens of thousands of Muslims having to migrate $^{43}$.

42 Istanbul University Library, Yıldı Albümü, http://nek.istanbul.edu.tr:4444/ekos/FOTOGRAF/90484---0004.jpg

43 Hüseyin Memişoğlu, Bulgaristan ve Bulgaristan Türk Azmlık Sorunu, TTK, Ankara 1992, p. 116; Ömer Turan, "Bulgaristan'da Türklere ve Müslümanlara Yapılan Mezâlim", Uluslararasi Suçlar ve Tarih Dergisi, No. 1, 2006, p. 93-98. 
Another development that was the subject of the relations between the Ottoman Empire and the Bulgarian Principality during the autonomy period was the annexation of Eastern Rumelia by the Bulgarian Principality and the Macedonian Question $^{44}$. In 1885, the Bulgarian Prince, with the support of Great Britain and Russia, annexed East Rumelia, to which the Ottoman Empire had appointed a governor immediately after the Berlin Treaty ${ }^{45}$. Subsequently, Macedonia started to instill nationalist ideas in the Bulgarian minority of Western and Eastern Thrace $^{46}$. Sultan Abdulhamid II preferred to remain unresponsive to this occupation except for dismissing Nihad Pasha, the commissioner of the Ottoman Empire in Sofia $^{47}$. There were two reasons for this. The first was that this region was a region with a low income and a constant cause for concern for the Ottoman Empire. The second was that he wanted to prevent Bulgarian cooperation with Russia ${ }^{48}$. Therefore, Abdulhamid II accepted with the edict he published on April 6, 1886, that Eastern Rumelia was Bulgarian territory ${ }^{49}$.

\section{Declaration of Independence of Bulgaria and Recognition of Bul- garia by the Ottoman Empire}

As we have stated above, although Bulgaria was a principality under the Ottoman Empire according to the Berlin Treaty, it acted as an independent state in practice. The Ottoman Empire had also accepted this situation.

In January 1908, the pro-independence Aleksandar Malinov government came to power, which included Nikolov, one of the leading actors of the annexation of Eastern Rumelia. In 1885, Bulgaria's independence process was accelerated ${ }^{50}$.

44 For detailed information on the Macedonian Question, see. Fikret Adanır, Makedonya Sorunu, Tarih Vakfi ,Yurt Yayınları, İstanbul 2001; Gül Tokay, Makedonya Sorunu: Fön Türk İhtilalinin Kökenleri, 1903-1908, AFA Yayınları, Istanbul 1996; Ahsene Gul Tokay, "Macedonian Reforms and Muslim Opposition during Hamidian Era 1878-1908", Islam and Christian-Muslim Relations, 14/ 1, 2003, pp. 55-65; Gül Tokay, "A Reassessment of the Macedonian Question, 1878-1908,", in Hakan Yavuz and Peter Sluglett (ed.), War and Diplomacy: The Russo-Turkish War of 1877-1978 and the Treaty of Berlin, Utah University Press, Salt Lake City 2011, p. 261-264; Mehmet Hacisalihoğlu, fön Türkler ve Makedonya Sorunu (1890-1918), Tarih Vakfi Yurt Yayınları, İstanbul 2020.

45 Bishku, "Ibid.”, p.79; Mahir Aydın, Şarki Rumeli...p. 15.

Rauf Ahmet Hotinli, “Bulgaristan”, MEB İslam Ansiklopedisi, 2, Eskişehir 2001, p. 302.

Mahir Aydın, "Bulgaristan..", p. 77.

48 Kara, "Ibid.", p. 546-547.

49 The Statesman's Year-Book - Statistical and Historical Annual of the States of the World for the Year 1911, Ed. J. Scott Keltie, Macmillan, and Co. Limited., London 1911, p. 671.

50 İsmail Yıldız, Osmanlı Devleti’nin Son Dönemlerinde Bulgaristan'daki Bağımsızlık Faaliyetleri (1878-1908), 
After establishing the Malinov Government, there was a severe increase in negotiations of the Bulgarian Prince with the European states ${ }^{51}$. So much so that the news that Bulgaria would announce its independence was soon published in European newspapers ${ }^{52}$.

In this process, the Ottoman Empire started diplomatic efforts to prevent it and presumed that the Great Powers would not recognize an independent Bulgaria ${ }^{53}$. Bulgaria's Kapi Kethuda in Istanbul, Ivan Evstratiev Gešov, was not invited to the dinner held for the representatives of foreign states on September 13, 1908, by Tevfik Pasha ${ }^{54}$, the Minister of Foreign Affairs in Istanbul, which led to the reaction of nationalist Bulgarians ${ }^{55}$. For this reason, Bulgarian Foreign Minister Stefan Paprikov sent a memorandum to the Ottoman Government, stating that they recalled Gešov and break off their political relations with the Ottoman Empire ${ }^{56}$. When Russian Foreign Minister Čarikov discussed about Bulgaria’s reaction with the Ottoman Empire's Ambassador to St. Petersburg, Turhan Pasha, Turhan Pasha stated that Bulgaria was not an independent country but a part of the Ottoman Empire and therefore Gešov could not be invited to the official dinner held for diplomatic representatives ${ }^{57}$.

After the Ottoman Empire declared the Second Constitutional Monarchy on July 23, 1908, the struggle for power in the Ottoman Empire began. Taking advantage of this situation, the Principality of Bulgaria declared its independence on October 5, 1908, at 11.00, by using the breaking off the relations as an excuse and taking advantage of the crisis with Austria over Bosnia and Herzegovina. On the

(Unpublished Master Thesis), Gazi University, Ankara 2008, p. 102-103.

51 Ylldı, Ibid., p. 102-103.

52 BOA. Y.A., HUS. 526/91, date: 07-02-1326 (hijri); BOA. Y.EE.KP. 33 /3227, date: 29-08-1326 (hijri).

53 BOA. Y.A.HUS., 525/121, date: 11-09-1326 (hijri).

54 For detailed information on this question see Mithat Aydın, "Bulgaristan Yol Ayrımında: Ivvan S. Geşov Meselesi”, Belleten, 77/280, 2013, p. 1077-1080.

55 Enver Ziya Karal, Osmanh Tarihi, .V., TTK, Ankara 1988, p. 227.

56 Harp Akademileri Komutanlığı, Türk Bulgar İliskilerinin Dünü-Bugünü-Yarnı, Harp Akademisi Basımevi, İstanbul 1995, p.34; Hasan Ünal, "Ottoman Policy during the Bulgarian Independence Crisis, 1908-9: Ottoman Empire and Bulgaria at the Outset of the Young Turk Revolution”, Middle Eastern Studies, 34/4, 1998, p. 142; Ali Fuat Türkgeldi, Görüp İsittiklerim, TTK, Ankara 1987, p. 10-11.

57 BOA. HR.ŞFR.1, 147/23, date: 14-09-1908. 
same day, Prince Ferdinand declared the independence of Bulgaria with the letter he sent to Abdulhamid II ${ }^{58}$. Bulgarian Prince Ferdinand also declared his kingship with the "tsar" title immediately after the declaration of independence ${ }^{59}$.

Bulgaria's declaration of independence was met with resistance in the Ottoman Empire. The Ottoman Empire declared that the necessary legal steps regarding this issue would be taken ${ }^{60}$. First, a protest telegram was sent to Prince Ferdinand. It was also attempted to establish an alliance with the Romanian, Greek, and Serbian governments against Bulgaria in order to maintain the political rights and financial status of the Ottoman Empire. The Ottoman Empire cooperated closely with Russia, Great Britain, and Italy on this issue ${ }^{61}$. To prevent Bulgaria's independence, the Ottoman Empire requested the member states of the Berlin Congress to discuss the issue ${ }^{62}$. However, a concrete result could not be achieved from these undertakings. Greece declared that it would comply with the decision of the Great Powers, while Russia stated that the matter should be settled with peace ${ }^{63}$. Although Great Britain protested against Bulgaria, they proposed to the Ottoman Empire to carefully examine the issue ${ }^{64}$. Serbia was concerned that Bulgaria would position itself against Serbia and it announced that they would support the Ottoman Empire if Bulgaria accumulated troops at the border ${ }^{65}$.

Meanwhile, Russia intervened and offered the Ottoman Empire to cancel the 125 million francs debt to Russia from the 1877-1878 Ottoman-Russian War in exchange to recognize Bulgaria's independence. When the Ottoman Empire, which did not receive any replies apart from advice from the Great Powers in its diplomatic initiatives after Bulgaria's independence, realized that it could not change

İkdam, 15. sene, Numara: 5161, 6 Teşrinievvel (October) 1908, p. 1; BOA. Y.PRK.NMH., 10/77, date: 09-09-1326 (hijri); Zafer Gölen, "İkinci Meşrutiyet Döneminde Bosna Hersek'in İlhakına Tepkiler", Toplumsal Tarih, No. 60, 1998, p.10.

59 Ömer Turan, The Turkish Minority in Bulgaria (1878-1908), TTK, Ankara 1998, p.76; Nazif Kuyucuklu, "Bulgaristan (Bağımsızlık Dönemi)", TDV İslâm Ansiklopedisi, Vol. 6, İstanbul 1992, p. 399.

60 BOA. BEO, 3410/255717, date: 09-09-1326 (hijri).

61 BOA. BEO, 3826/286878, date: 11-01-1326 (hijri).

62 A. Gül Tokay, "Osmanlı-Bulgar İlişkileri (1878-1908)”, Osmanh, 2, Yeni Türkiye Yayınları, Ankara 1999, p. 326.

63 BOA. Y.A.HUS., 525/121, date: 11-09-1326 (hijri).

64 BOA. A.\}MTZ. (04), 171/72, date: 21-09-1326 (hijri).

65 BOA. Y.A.HUS., 525/121, date: 11-09-1326 (hijri). 
the situation, it focused on Russia's offer for compensation ${ }^{66}$. Russia's particular desire to establish peace between Bulgaria and the Ottoman Empire was related to its fear of the current status quo in the Black Sea and the Straits being returned to the status quo of the Paris Treaty of 1856. If the Ottoman Empire brought the question of Bulgaria's independence to an international conference, the Berlin Treaty would have been disrupted and the situation in the Black Sea could become undesirable for Russia. This was the reason for peaceful settlement ${ }^{67}$. Rifat Pasha, the Minister of Ottoman Foreign Affairs, went to Petersburg and met with the Minister of Foreign Affairs of Russia Alexander Izvolsky to a protocol on this topic on March 7, $1909^{68}$. Following the conditions of this protocol, the Istanbul Protocol was also signed between the Ottoman Foreign Minister Rifat Pasha and Russian Foreign Minister Alexander Izvolsky on April 19, 1909. With this protocol, the Ottoman Empire recognized the independence of Bulgaria ${ }^{69}$. 125 million francs of war compensation was given to the Ottoman Empire by Bulgaria, which was deducted from the Ottoman Empire's debt to Russia from the 1877-1878 Ottoman - Russian War ${ }^{70}$. With an additional protocol made after this treaty, Muslims in Bulgaria had minority rights and their rights in education and religion were guaranteed ${ }^{71}$.

The topic that the Ottoman Empire was perhaps the most concerned with after the independence of Bulgaria was Ferdinand's title. The Ottoman Government believed that using the title Bulgarian King instead of the title of Tsar from time to time would impact the Bulgarians in Macedonia, therefore in the official correspondence, Ferdinand was addressed with the title of the King of Bulgaria by the Ottoman Empire ${ }^{72}$. However, as of 1910, they began to address him with the title of

67

Vatansever, Ibid, p. 196. 240; E.R., "İcmal-i Dahili", İstişare, 1/5, 4 Tesrin-i Evvel 1324 (October 17, 1908), p. 231-236.

BOA. HR.HMŞ.İŞO. 28/17, date: 01-11-1325 (rumi); Türkgeldi, Ibid, p. 13-14.

Bilal N. Şimşir, Bulgaristan Türkleri (1878-1985), Bilgi Yayınevi, Ankara 1986, p.368-370; Yusuf Sarınay, "Osmanlı Devleti’nin Bulgaristan’ın Bağımsızlığını Tanıması ve Türk-Bulgar. İlişkilerinin Gelişmesi (1908-1914)", Uluslararası Osmanl ve Cumhuriyet Dönemi Türk Bulgar Illişileri Sempozyumu, 11-13 Mayıs 2005 Eskişehir - Türkiye Bildiriler Kitabı, Mayıs 2005 p.134; Avcı, "Ibid”, p.293; Çetin, Ibid, 275.

70 Sarınay, "Ibid". p. 134; Yıldız, Ibid., p. 104; Avcı, "Ibid", p. 293; Yıldız, Ibid., p. 104;

71 Türkgeldi, Ibid., p. 268-370.

72 BOA. DH.MUI., 57/6, date:10-01-1328 (hijri). 
Bulgarian King ${ }^{73}$ and the visit of King Ferdinand I and his wife to Istanbul in March $1910^{74}$ contributed to this. The title of Tsar was met with resistance from Russia, as he used this tittle on the funeral of the Grand Duke of Russia in St. Petersburg. His visit to Istanbul ${ }^{75}$ also had the same effect.

\section{Establishment of Embassies and Mustafa Asım Bey's Sofia Ambassadorship}

After the Ottoman Empire recognized Bulgaria by the Istanbul Protocol, the two states appointed ambassadors mutually. Bulgaria appointed Mihail K. Sarafov as an ambassador to Istanbul ${ }^{76}$, while the Ottoman Government appointed Stockholm ambassador Mustafa Asim Bey, an experienced diplomat, as an envoy extraordinary. Mustafa Sekib Bey, who represented the Ottoman Empire as a Commissioner in Sofia, was appointed as ambassador to Stockholm ${ }^{77}$,

\section{a. Biography of Mustafa Asim Bey}

A member of the Meclis-i Emval-i Eytam (Orphanage's Administrative Council) and of Harameyn-i Muhteremeyn ${ }^{78}$, the son of Ahmed Rifat Bey of the family of Hocaoğulları, Mustafa Asım Bey ${ }^{79}$ was born in Istanbul on December 10, 1868. After studying at the Soğgkçeşme Askeri Rüşdiyesi (Sogukcesme Military Middle School), he continued his education at the Mekteb-i Sultanî(Galatasaray Imperial High School). However, he could not complete his education here because of his father's death. He was literate in Turkish, French, and Italian. He was also familiar with Arabic and Persian ${ }^{80}$. (hijri).

75 Avcr, "Ibid", p. 294.

76 Avcr, "Ibid", p. 293.

77 


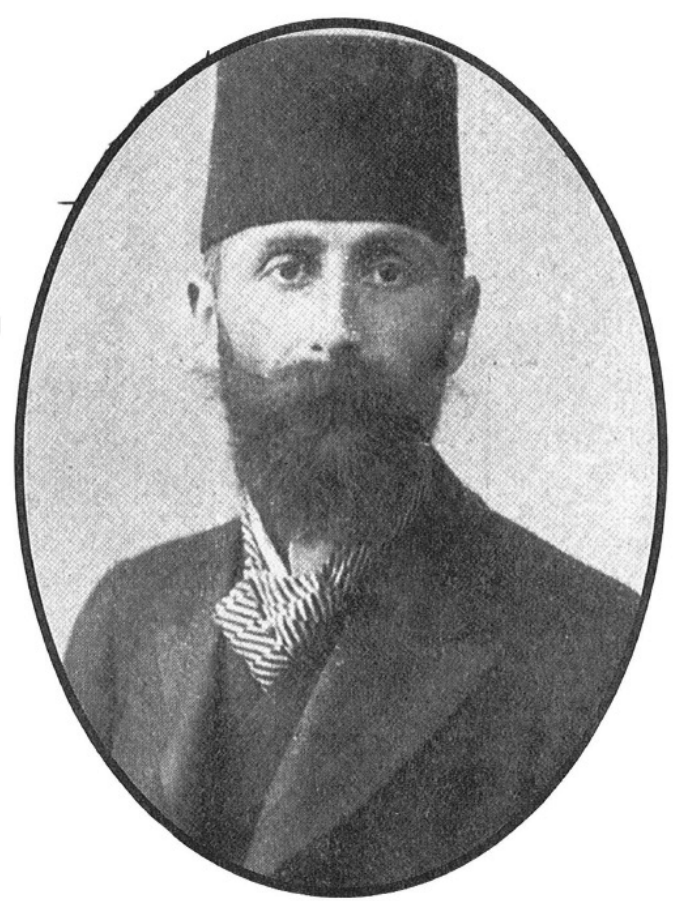

Photo 2: Mustafa Asim Bey ${ }^{81}$

On January 18, 1887, he was admitted to the Divan-ı Hümayun Kuyûd Odasi (Imperial Council Register Office) as an intern and then to the Umûr-ı Şehbenderî Kalemi (Directorate Consular Affairs) with the denotation of Umûr-ı Şehbenderî Müdürü (Director of Consular Affairs) Semseddin Pasha ${ }^{82}$. On August 5, 1888, he was appointed to the Pest embassy chancellery ${ }^{83}$.

The Austrian state awarded him the Fifth Class Order of Franciscan Foseph on June 21, $1893^{84}$. On August 23, 1892, he was appointed to the Consulate at Kufa ${ }^{85}$. On October 21, 1892, he was appointed to the Consulate at Kragujevac ${ }^{86}$.

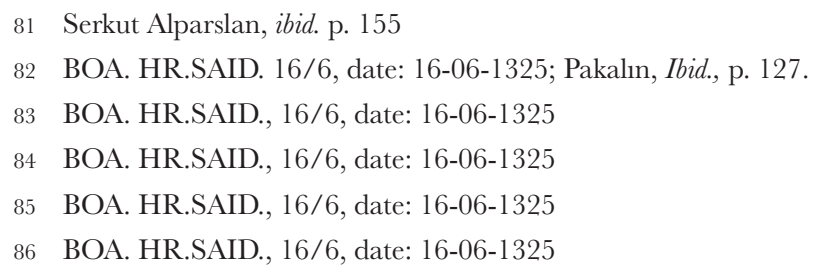


He was appointed to Niš Consulate on March 13, 1897. He did not work here for long and was promoted to the First Secretary of the Belgrade Embassy on April 20, 1897. Mustafa Asım Bey was given the Fourth Class Nişan-1 Ali Osmanî on December 6, 1898, for his services ${ }^{87}$.

On August 7, 1901, he was appointed to Marseille as the General Consulate. He was appointed to the Berlin Embassy as First Secretary on August 28, 1901, with the same salary. He received the Second Class Order of Mecidî on June 11, 1903, because of his successful work there ${ }^{88}$.

On July 21, 1903, he was appointed as the First Secretary of the Vienna Embassy. He was promoted to the Undersecretariat of the Vienna Embassy on July 5, $1904^{89}$.

Then he was appointed to the Brussels Embassy as ambassador in April $1908^{90}$. However, he was ordered to return to Istanbul to receive his credentials and was held there for 3 months, and then appointed to the Stockholm Embassy in July 1908. Therefore, this duty to which he was appointed before he could go to Brussels as Ambassador ended ${ }^{91}$.

Mustafa Asim Bey was appointed to Sofia as envoy extraordinary in June 1909 while he was the Ambassador to Stockholm. Mustafa Sekib Bey, who represented the Ottoman Empire as the Commissioner in Sofia, was appointed as ambassador to Stockholm ${ }^{92}$.

Mustafa Asım Bey served as Foreign Minister between October 1911 and July 1912 in the Said Pasha's government after serving as the ambassador in Sofia ${ }^{93}$. Between January 1914 and February 1916, he served as the Ambassador to Teh$\operatorname{ran}^{94}$.

BOA. HR.SAID. 16/6, date:16-06-1325

BOA. HR.SAID. 16/6, date:16-06-1325

90 Kuneralp, Ibid., p. 108.

91 BOA. ŞD. 2780/39, date: 22-02-1327 (hijri).

92 BOA. BEO. 3578/268308, date: 01-06-1327 (hijri).

93 İsrafil Kurtcephe, "Osmanlı Parlamentosu ve Türk-İtalyan Savaşı (1911-1912)", OTAM Dergisi, 4, 1993, p. 237; Kuneralp, Ibid., p. 108.

94 Kuneralp, Ibid., p. 108. 
After his post as the Tehran Ambassador, Mustafa Asım Bey moved to Vienna with his Austrian wife and his children and lived there between 1916-193195. On his return to Turkey, Mustafa Asım Bey took the surname Turgut when the Surname Law (Turkey) was adopted in 1934. Mustafa Asım Bey passed away in $1937^{96}$.

\section{b. Mustafa Asım Bey's Sofia Ambassadorship (June 1909 - October 1911)}

The Sublime Porte deemed the Ambassador of Stockholm Asim Bey to be suitable for the post of Ambassador to Sofia. On June 8, 1909, the Bulgarian Ministry of Foreign Affairs and Religious Denominations reported to Ferdinand's secret cabinet secretary Dobrovic that the Sublime Porte was considering the appointment of the Stockholm ambassador Asim Bey as the Sofia ambassador ${ }^{97}$. After the Bulgarian Government accepted his appointment Mustafa Asım Bey was appointed to Sofia as envoy extraordinary in June $1909^{98}$.

Although Mustafa Asım was appointed as the envoy extraordinary to the Sofia Embassy in June 1909, he arrived in Sofia on September 3, 1909 ${ }^{99}$. We think that this delay might be caused by the fact the Bulgarian Tsar was outside of Sofia. Bulgaria's ambassador to Istanbul, Mihail K. Sarafov, wrote in the letter he sent to Sofia on August 3, 1909, that Mustafa Asim Bey was waiting for Tsar's return to Sofia to come to Bulgaria and was inquiring when he would be back ${ }^{100}$. In his letter to Istanbul, Mustafa Asim Bey stated that he had reached Sofia, aware of the importance of his duty, and would work to protect the right of the Ottoman Empire, and would constantly check whether the Ottoman officials in Bulgaria were working towards this goal ${ }^{101}$. Mustafa Asim Bey presented his ambassador credentials to the Bulgarian King on September 14, 1909, and officially started his duty ${ }^{102}$.

95 Esma İgüs Parmaksız - Pınar Bolel Koç, "Arşiv, Kadın, Kimlik: MSGSÜ Resim Heykel Müzesi Arşivinden Leyla Turgut Terekesi", "Women's Memory: The Problem of Sources" $20^{\text {th }}$ Anniversary Symposium of the Women's Library and Information Centre Foundation 17-19 April 2009, İstanbul 2009, p. 148.

96 Kuneralp, Ibid., p. 108.

97 Bayraktarova, Ibid., p. 33.

98 BOA. BEO. 3578/268308, date: 01-06-1327 (hijri).

99 BOA. HR.ŞFR.04. 614/106, 30-08-1909

100 Bulgaria National Archive, fund 176K, archival reference book 14, archival unit 936, nu.2432.

101 BOA. HR.ŞFR.04. 614/106, 30-08-1909

102 Avc1, "Ibid.", p. 293. 


\section{Conversion of Trader's Representations to Consulates}

Before the Ottoman Empire officially recognized Bulgaria, it had started the necessary diplomatic preparations. One of the first actions carried out in this context was converting the Trader's Representations in Bulgaria into consulates ${ }^{103}$. After Bulgaria was officially recognized and Mustafa Asım Bey was appointed to Sofia, the consulate issue was emphasized. With the consulate agreement signed between the Ottoman Empire and Bulgaria on December 27, 1909 ${ }^{104}$, the Ottoman Empire's Trader's Representation in Plovdiv was converted into Consulate General, while the Trader's Representations in Sofia, Varna, Ruse, and Burgas were converted into consulates. The Trader's Representation at Vidin was converted to a consulate. Bulgaria's Trader's Representations in Istanbul and Thessaloniki were converted into Consulate Generals, while those in Edirne, Bitola, Skopje, and Serres were converted into consulates ${ }^{105}$.

\section{The Effect of Mustafa Astm Bey on the Ottoman-Bulgarian Relations During his Time as Ambassador}

The most critical issues that were the subjects of the relations between the two states during Mustafa Asim Bey's ambassadorship were the land and real estate problems of Ottoman citizens in Bulgaria and Bulgarian citizens in the Ottoman Empire, laws on religious matters ${ }^{106}$, border regulations, bandit attacks on the border, and commercial relations between the two countries.

Before Mustafa Asım Bey presented his credentials, the first subject he worked on in Sofia was the ongoing border dispute between the Ottoman Empire and Bulgaria. In a meeting with Bulgarian Foreign Minister Stefan Paprikov on September 1, 1909, setting up a commission for dealing with the border dispute and solving the issue as soon as possible were discussed ${ }^{107}$. While trying to solve the border dispute with the commission, tensions between the two sides' soldiers were frequently experienced at the border.

103 BOA. HR.ŞFR.04. 834 / 106, 08-04-1909; Serkut Alparslan, Meşrutiyet Dönemi Hariciye Nazirlarindan Asim Bey'in (Mustafa Asim Turgut) Osmanli/Türk Diplomasisindeki Yeri (1908-1918), (Unpublished Master. Thesis), Dokuz Eylul University, Intitute of Social Sciences Department of History, Izmir 2018, p. 44.

104 BOA. A. \{DVNSDVE.d. 8/2, date: 29-11-1329 (hijri).

105 BOA. A \{DVNSDVE.d. 8, date: 29-11-1329 (hijri).

106 Bulgaria National Archive, fund 176K, archival reference book 14, archival unit 936.

107 BOA. HR.ŞFR.04. 486/32, 01-09-1909 
Mustafa Asim Bey sometimes reported to Istanbul and discussed with the Bulgarian Government the situations when the soldiers fired guns at each other. The border dispute could not be solved during the ambassadorship of Mustafa Asim Bey $^{108}$.

One of the crucial interactions between the Ottoman Empire and Bulgaria was commercial relations. It was necessary to form a trade agreement with Bulgaria. Looking at the Bulgarian trade volume of 1906, shown in the table below, it can be seen that the most exports were made to the Ottoman Empire. As for imports, the Ottoman Empire is in the third place.

Table 2: Imports and Exports of Bulgaria for $1906^{109}$

\begin{tabular}{|l|c|c|}
\hline \multicolumn{1}{|c|}{ Country } & $\begin{array}{c}\text { Imports from } \\
\text { (Leva) }\end{array}$ & $\begin{array}{c}\text { Exports to } \\
\text { (Leva) }\end{array}$ \\
\hline United Kingdom & 19.600 .531 & 14.985 .084 \\
\hline Austria-Hungary & 27.802 .354 & 8.200 .131 \\
\hline Turkey & 18.052 .512 & 21.699 .345 \\
\hline Germany & 16.224 .543 & 15.409 .790 \\
\hline Belgium & 3.078 .018 & 20.141 .790 \\
\hline France & 5.372 .550 & 8.977 .234 \\
\hline Italy & 5.543 .411 & 3.905 .497 \\
\hline Russia & 4.648 .702 & 306.142 \\
\hline
\end{tabular}

To regulate the trade relations between the two countries, the Trader's Representations that were established before Bulgaria's independence were converted into consulates in both countries. Then, the action was taken to sign a trade agreement between the two countries. The Bulgarian Government took the first step in this regard, requesting in January 1910 for the trade treaty previously signed between the two countries ${ }^{110}$ to be renewed. Finally, in 1911, a "trade and navigational treaty" was signed between the Bulgarian Government and the Ottoman Government ${ }^{111}$. It was observed that Mustafa Asim Bey put a lot of effort and time into

108 BOA. HR.ŞFR.04. 486/41, date: 25-09-1909; HR.ŞFR.04. 486/43

109 The Statesman's Year-Book - Statistical and Historical Annual of the States of the World for the Year 1908, Ed. J. Scott Keltie, Macmillan, and Co. Limited, London 1911, p. 1588.

110 Customs Treaty of January 9, 1907 (BOA. MV. 127/29, date: 29-04-1327-hijri-).

111 Erol, "Ibid", p.226. 
the negotiations for this agreement, eliminating the problems, and reported the negotiations to Istanbul frequently ${ }^{112}$.

Another issue that Mustafa Asım Bey was interested in was the protection of the rights of Ottoman citizens. Military service was one of the subjects he was most interested in. The Bulgarian Government was recruiting for the army through the military commission created after independence ${ }^{113}$. During this period, Ottoman citizens residing in Bulgaria were also subject to compulsory enlistment. In an exemplary incident, the Sofia Embassy interfered to stop the Ottoman citizen Goskian Aga, who was residing in Burgas, from being enlisted and succeeded ${ }^{114}$.

A subject that Mustafa Asim Bey spent much time on in Bulgaria was the committees' activities in Bulgaria and Macedonia. During this period, Bulgarian and Armenian committees were actively working in both Bulgaria and Macedonia ${ }^{115}$. In this context, the Embassy regularly informed Istanbul about the committee in Macedonia and the support they received from Bulgaria ${ }^{116}$. Mustafa Asim gave detailed information about the developments in the reports he sent frequently. In one report, he stated that although the Bulgarian Government declared that it would prevent the committee from crossing the border, in reality the Bulgarian Government did not prevent it and explained the support given by the Bulgarian Government to the committees in Bulgaria and Macedonia ${ }^{117}$.

Another affair Mustafa Asim Bey was concerned wiht was the Grand Mufti's election in Bulgaria ${ }^{118}$. While the Mufti of Sofia, Hocazade Mehmet Muhiddin Efendi, was endorsed by the Bulgarian Government for Grand Mufti, Mustafa

112 BOA. HR.SFR.04. 250/7, date: 24-01-1911; BOA. HR.ŞFR.04. 250/15, date: 29-01-1911.

113 İbrahim Serbestoğlu, "Balkan Devletlerindeki Müslümanların Tabiiyeti (1830-1930)", Mübadele, Şen Gittikङ Yash Döndük, Samsun 2011, p. 131.

114 BOA. HR.SFR.04. 841/22, date: 11-11-1909.

115 For Armenian and Bulgarian Committees in Bulgaria and Macedonia see Bülent Yıldırım, Bulgaristan'daki Ermeni Komitelerinin Osmanh Devleti Aleyhine Faaliyetleri (1890 - 1918), TTK, Ankara 2014, p.41-190; Mahir; Aydın, "Arşiv Belgeleriyle Makedonya'da Bulgar Çete Faaliyetleri," Osmanh Arasttrmalar, V. IX., 1989, p. 209- 234; Adanı, Ibid.

116 BOA. BEO. 3665/274840, date: 07-11-1327 (hijri).

117 BOA., HR.SYS., 2950/81, date:26-07-1910

118 For the status of the muftis in Bulgaria and the problems experienced, see Kemal Yakut, Meral Bayrak (Ferlibaş), "Osmanlı'dan Cumhuriyet'e Bulgaristan Müftülerinin Statüsü (1878-1929)", Uluslararası Osmanlı ve Cumhuriyet Dönemi Türk Bulgar İlişkileri Sempozyumu, 11-13 Mayıs 2005 Eskişehir - Türkiye, Bildiriler Kitabr, Mayns 2005, p. 335-343. 
Asim Bey believed that the Muslims in Bulgaria would lose their rights if Mehmet Muhiddin Efendi was elected as a mufti again. And in his opinion this should have been prevented. Despite the lobbying of Mustafa Asim Bey, in the elections held on December 8, 1910, Hocazade Mehmet Muhiddin Efendi was elected as the Grand Mufti with 25 votes. His competitor, Mufti of Vidin Suleyman Rusdi, received 9 votes $^{119}$.

One of the most critical issues between Bulgaria and the Ottoman Empire was the issue of Muslim waqfs. After Bulgaria gained independence, Muslim waqfs were systematically seized, which caused problems between the two countries. The questions of Muslim waqfs were added to March 7, 1909, Petersburg Protocol ${ }^{120}$ and the Istanbul Protocol, with which the Ottoman Empire recognized the independence of Bulgaria on April 19, 1909 ${ }^{121}$. Accordingly, recognition of Bulgaria's independence was dependent on the establishment of a commission regarding the waqfs ${ }^{122}$. In this context, the Bulgarian Government established a commission consisting of only Bulgarians on July 27, 1909. The commission, starting its activities, prepared a report on October 27, 1909. The report decided that the term "exceptional" in the Istanbul Protocol would apply only to the waqfs not affiliated with the Evkaf Ministry. The Commission rejected all applications for taking back of 42 waqfs on different grounds such as lack of documents ${ }^{123}$.

General elections were held on September 4, 1911, during Mustafa Asim Bey's last year at his post in Sofia. In these elections, he provided detailed information about the parties and leaders who won the greates number of votes. These were the People Party and its leader Gešov, the Progressive Liberal Party and its leader Rankov and the members of the established Government ${ }^{124}$. Prime Minister Gešov, who established the New Government, stated to Mustafa Asım Bey that the border regulations would determine his relations with the Ottoman Empire ${ }^{125}$.

119 Bayraktarova, Ibid., p. 115-125.

120 BOA. HR.HMŞ.IŞSO. 28/17, date: 01-11-1325 (rumi).

121 Neriman Ersoy Hacısalihoğlu, "Bulgaristan'da "Müstesna Vakıflar" ve 1909 Yılı Komisyon Kararları", Tarih Dergisi, 46, İstanbul 2009, p. 157.

122 BOA. HR.HMŞ.IŞSO. 28/17, date: 01-11-1325 (rumi).

123 Hacisalihoğlu, "Ibid.", p. 160-167.

124 BOA. HR.ŞFR.04. 277/7, date: 30-03-1911.

125 BOA. HR.SFR.04. 277/9, date: 10-04-1911. 
Mustafa Asim Bey was given the "Merit Civil Order" by the Bulgarian King in January 1912 at the time when he was the foreign minister. This order given to Mustafa Asım Bey caused great controversy in Bulgaria. The nationalist Bulgarian poet Peyo Yavorov was one of the people who expressed the disagreement. Peyo Yavorov, who had participated in the Ilinden Uprising in Macedonia in 1903, expressed his reaction in the Vardar Newspaper with an article titled "Asim Bey Has Been Honored" with the following sentences ${ }^{126}$ :

"Bulgarian Tsar" awarded Turkish Foreign Minister Asım Bey with a firstdegree service medal! Isn't this an insult with the title "Bulgarian Tsar"? When some Bulgarians were subjected to systematic slaughter by Asim Bey's political friends and when the Macedonian Bulgarians desperately scream because of the persecution by the decapitators of the Committee of Union and Progress, the "Bulgarian Tsar" awards Asim Bey! For which service was this medal awarded to him?..."

Mustafa Asim Bey was presented the medal by Sarafov, the Istanbul Ambassador of Bulgaria, on January 12, $1912^{127}$.

\section{Conclusion}

Although Bulgaria was a part of the Ottoman Empire, it acted as an independent state in practice in accordance with the Berlin Treaty. The Ottoman Empire also accepted this situation. After the Ottoman Empire declared the Second Constitutional Monarchy on July 23, 1908, the struggle for power in the Ottoman Empire began. Taking advantage of this situation, the Principality of Bulgaria declared its independence on October 5, 1908, at 11.00, by using the breaking of ties as an excuse. The Ottoman Empire recognized the independence of Bulgaria with Istanbul Protocol which was signed between the Ottoman Foreign Minister Rifat Pasha and Russian Foreign Minister Alexander Izvolsky on April 19, 1909.

After the Istanbul Protocol, the two states appointed their respective ambassadors. Bulgaria appointed Mihail K. Sarafov to Istanbul as an ambassador, while the Ottoman Government appointed Stockholm ambassador Mustafa Asim Bey, an experienced diplomat, as an envoy extraordinary.

126 Peyo Yavorov, “Асим бей награден (Asim Bey rewarded)” ВАРДАР (Vardar Newespaper), 12 January 1912

127 Tsentralen Darzhaven Istoricheski Arhiv, fund 176K, archival reference book 14, archival unit 936, nu.339. 
Mustafa Asım Bey had an essential role in being the first ambassador of the Ottoman Empire in Sofia. The problems between the Ottoman Empire and the newly independent Bulgaria were both those that started in 1878 and also new problems brought by a new embassy.

During the ambassadorship of Mustafa Asım Bey, many administrative problems were solved. These included the Ottoman Empire's acceptance of King Ferdinand, giving himself the title Bulgarian King, converting the Trader's Representations in the two countries into consulates, the resolution of the Grand Mufti issue, and the trade agreement. However, some problems could not have been solved during Asım Bey's period. Border disputess and the foundations' problem were some of them.

During his tenure, Mustafa Asım Bey regularly reported to Istanbul the political developments in Bulgaria and the information he gained in Bulgaria regarding the Macedonian Question.

Mustafa Asım Bey had a successful ambassadorship in general. However, he could not notice the approchement of Bulgaria with Serbia through Russia and in his speech to the Parliament during his time as Foreign Minister he even stated that he was sure that Bulgaria would not go to war against the Ottomans ${ }^{128}$.

128 Ahmet Ali Gazel, "Osmanlı Devleti’nde Balkan Savaşı Yenilgisinin Siyasi Sorumluları”, Balkan Tarihi, Vol. 1, Gece Kitaplı̆̆ı, Ankara 2016, p. 398. 


\section{BIBLIOGRAPHY}

\section{Archive Documents}

a. Directorate of State Archives Ottoman Archives (İstanbul) $\left(\right.$ BOA) ${ }^{129}$ BOA. A. \{DVNSDVE.d.

BOA. A. $\}$ MTZ.(04).

BOA. BEO.

BOA. DH.EUM.THR.

BOA. DH.ID.

BOA. DH.MUI.

BOA. DH.SAIDd.

BOA. HR.HMŞ.ISSO.

BOA. HR.SAID.

BOA. HR.SFR.1.

BOA. HR.SFR.04..

BOA., HR.SYS.

BOA. HR.UHM.

BOA. I..HR.

BOA. I.MBH.

BOA. I.MTZ.(04).

BOA. MV.

BOA. ŞD.

BOA. Y.A.HUS.

BOA. Y.EE.KP.

BOA. Y.PRK.NMH.

\section{b. Tsentralen Darzhaven Istoricheski Arhiv (Bulgaria)}

Fund 176K, archival reference book 14, archival unit 936.

\section{Periodicals}

\section{a. Newspapers}

Pеyo Yavorov, “Асим бей награден (Asim Bey rewarded)”, ВАРДАР (Vardar Newspaper), 12 January 1912

E. R., "İcmal-i Dahili”, İstişare, Vol. 1/No. 5, 4 Teşrin-i Evvel 1324 (October 17, 1908), p. 231-236.

129 Catalog numbers are shown in footnotes. 
İkdam, 15. sene, Nu: 5161, 6 Teşrinievvel (October) 1908.

Mehmed Salih, "İcmal-i Harici”, İstişare, Vol. 1/No. 5, 4 Teşrin-i Evvel 1324 (October 17, 1908), pp. 237-240.

\section{b. Annuals}

The Statesman's Year-Book - Statistical and Historical Annual of the States of the World for the Year 1911, Ed. J. Scott Keltie, Macmillan, and Co. Limited, London 1911.

The Statesman's Year-Book - Statistical and Historical Annual of the States of the World for the Year 1908, Ed. J. Scott Keltie, Macmillan, and Co. Limited, London 1911.

\section{Literature}

Adanır, Fikret, Makedonya Sorunu, Tarih Vakfi Yurt Yayınları, istanbul 200.

Alparslan, Serkut, Meşrutiyet Dönemi Hariciye Nazirlarindan Asim Bey'in (Mustafa Asim Turgut) Osmanli/Türk Diplomasisindeki Yeri (1908-1918), (Unpublished Master. Thesis), Dokuz Eylul University, Intitute of Social Sciences Department of History, Izmir 2018

Altıntaş, Ahmet, "Makedonya Sorunu ve Çete Faliyetleri”, Afyon Kocatepe Üniversitesi Sosyal Bilimler Dergisi , 7/2, 2005, pp. 69-91.

Avcı, Yasemin, "Bağımsız Bulgaristan ile Osmanlı Devleti Arasında 'Modern Diplomasi' (1908-1912)", Uluslararası Osmanlı ve Cumhuriyet Dönemi Türk Bulgar İlişkileri Sempozyumu, 11-13 Mayıs 2005 Eskişehir - Türkiye Bildiriler Kitabı, Mayıs 2005, pp.291-296.

Aydın, Mahir, "Arşiv Belgeleriyle Makedonya'da Bulgar Çete Faaliyetleri," Osmanlı Arastirmalar, IX, 1989, pp. 209-234.

Aydın, Mahir, "Bulgaristan Komiserliğì", Belgeler, Türk Tarih Belgeleri Dergisi, XVIII/21, TTK, Ankara 1997, pp. 71-125.

Aydın, Mahir, Osmanl Eyaletinden Ǚ̧üncü Bulgar Çarlğ̆nna, Kitabevi, İstanbul 1996.

Aydın, Mahir, Şarkî Rumeli Vilâyeti, TTK, Ankara 1992.

Aydın, Mithat, Balkanlar'da İsyan, Yeditepe Yayınevi, İstanbul 2005.

Aydın, Mithat, "Bulgaristan Yol Ayrımında: İvan S. Geşov Meselesi", Belleten, 77/280, 2013, p. 1071- 1102. 
Aydın, Mithat, "Bükreş’te Komitacılık Faaliyetleri (1860-1916)", Fournal of Modern Turkish History Studies, XV/30 (2015-Spring), pp. 5-52

Aydın, Mithat, “Osmanl1-İngiliz İlişkilerinde İstanbul Konferansı (1876)'nın Yeri”, Ankara Üniversitesi Dil ve Tarih-Coğrafya Fakültesi Tarih Bölümü Tarih Araştırmalan Dergisi, 25/39, 2006, pp. 101-115.

Balc1, Tamer, "Ottoman Balkan Heritage and The Construction of Turkish National Identity", Osmanh Mirası Araştırmalan Dergisi (fournal of Ottoman Legacy Studies), 1/1, November 2014, pp. 60-70

Bayraktarova, Emine, Osmanl Devleti-Bulgaristan Prenslĭ̆i İlişkileri (1878-1908), (Upublished Ph.D. Thesis), Marmara University, Institute of Turkic Studies), İstanbul 2002

Bishku Michael B., "Turkish-Bulgarian Relations: From Conflict and Distrust to Cooperation", Mediterranean Quarterly, 14/2, Spring 2003, pp. 77-94.

Borysova, Olga; Karpitsky, Nikolai, "Father Paisii Hilendarski`s Message About the Volga Ancestral Home of the Bulgarians as a Source of Formation of National Historical Consciousness", Gournal of International Eastern European Studies, 1/2, Winter, 2019, pp. 247-260.

Crampton, Richard J., Bulgaria, Oxford University Press, 2007.

Çetin, Erol, Bulgaristan Prenslĭgi ve Osmanl İmparatorluğu Arasında Siyasi Ilişkiler (18781908), (Unpublished Ph.D. Thesis), Istanbul University, Istanbul 2003.

Davidova, Evguenia, "A Centre in the Periphery: Merchants during the Ottoman period in Modern Bulgarian Historiography (The 1890s - 1990s)" Fournal of European Economic History, 31/3, 2002, pp. 663-685.

Eminov, Ali, "Social Construction of Identities: Pomaks in Bulgaria", JEMIE, 6/2, 2007, pp. 1-25.

Erol, Yasemin Zahide, "Şehbender Raporlarına Göre Osmanlı-Bulgaristan Ticari İlişkileri (1910-1914)", TAD, 34/57, 2015, pp. 221-248.

Ersoy Hacısalihoğlu, Neriman, "Bulgaristan'da "Müstesna Vakıflar" ve 1909 Yılı Komisyon Kararları", Tarih Dergisi, 46, İstanbul 2009, pp. 155-176.

Gazel, Ahmet Ali, “Osmanlı Devleti’nde Balkan Savaşı Yenilgisinin Siyasi Sorumluları”, Balkan Tarihi, 1, Gece Kitaplığı, Ankara 2016, pp. 381-412. 
Gencer, Ali İhsan, "Berlin Antlaşması", TDV İslâm Ansiklopedisi, 5, İstanbul 1992, pp. 516-517.

Gökbilgin, M. Tayyib, Rumeli'de Yürükler, Tatarlar ve Evlâd-ı Fâtihân, İstanbul Üniversitesi Edebiyat Fakültesi Yayınları, İstanbul 1957.

Gölen, Zafer, "İkinci Meşrutiyet Döneminde Bosna Hersek’in İlhakına Tepkiler", Toplumsal Tarih, No. 60, 1998, pp. 9-16.

Gölen, Zafer, "Karadağ Devletinin Doğuşunda Büyük Güçlerin Rolü (18501875)“, Almanah, 63-64, Podgorica 2014, pp. 171-187.

Gölen, Zafer, "Osmanlı Yurdu Olan Bosna-Hersek'te XIX. Yüzyıldaki Siyasi Olaylar", Belleten, LXXIV/270, August 2010, pp. 421-475.

Güllü, Ramazan Erhan, “Bulgar Eksarhlığı'nın Kuruluşu ve Statüsü”, Gaziantep University Journal of Social Sciences, 17/1, 2018, pp. 350-361.

Hacısalihoğlu, Mehmet, fön Türkler ve Makedonya Sorunu (1890-1918), Tarih Vakfi Yurt Yayınları, Istanbul 2020.

Halaçoğlu, Yusuf, "Bulgaristan (Osmanlı Dönemi)", TDV İslâm Ansiklopedisi, Vol. 6, İstanbul 1992, pp. 396-399.

Harp Akademileri Komutanlığı, Türk Bulgar İlişkilerinin Dünü-Bugünü-Yarmı, Harp Akademisi Basımevi, İstanbul 1995.

Hotinli, Rauf Ahmet, "Bulgaristan", MEB İslam Ansiklopedisi, Vol. 2, Eskişehir 2001, pp. 301-303.

İnalcık, Halil, Osmanh İmparatorluğu Klâsik Çağ (1300-1600), YKY, İstanbul 2003. İnalckk, Halil, Tanzimat ve Bulgar Meselesi, Eren Yayınları, İstanbul 1992.

İnbaş1, Mehmet, "XVI-XVII. Yüzyıllarda Bulgaristan'daki Yörük Yerleşmeleri", Uluslararası Osmanl ve Cumhuriyet Dönemi Türk Bulgar Illişkileri Sempozyumu, 11-13 Mayıs 2005 Eskişehir-Türkiye Bildiriler Kitabı, Mayıs 2005, pp. 171-187.

Kara, Hidayet, "Sultan II. Abdulhamid Dönemi Balkanları Üzerine Bir Değerlendirme: Goltz Paşa'nın Balkan Meselesine Dair Görüşleri”, Anemon Muş Alparslan Üniversitesi Sosyal Bilimler Dergisi, 8/2, 2020, pp. 545-558.

Karal, Enver Ziya, Osmanl Tarihi, Vol. V. and VIII, TTK, Ankara 1988.

Kayapınar, Ayşe, "Bulgaristan'da Osmanlı Hakimiyetinin Kurulması: Dönemlendirme Sorunu ve İskân", Tïrk Tarihinde Balkanlar, Editörler: Zeynep İskefiyeli, 
M. Bilal Çelik, Serkan Yazıcı, Sakarya Üniversitesi, Balkan Araştırmaları Uygulama ve Araştırma Merkezi Yayınları, Sakarya Haziran 2013.

Kohn, Hans, Pan-Slavism-Its History and Ideology, University of Notre Dame Press, Indiana 1953.

Korkmaz, Nuri, "Bulgar Milliyetçiliğinin Doğuşu, Ortodoks Unsurları, Gelişimi ve Türklerin Ötekileştirilmesi”, Gazi Akademik Bakış, 20/20, 2017, pp. 69-82.

Kuneralp, Sinan, Son Dönem Osmanh Erkan ve Ricali (1839-1922), ISIS Yayınları, İstanbul 1991.

Kurtcephe, İsrafil "Osmanlı Parlamentosu ve Türk-İtalyan Savaşı (1911-1912)", OTAM Dergisi, 4, 1993, pp. 235-258.

Kuyucuklu, Nazif, "Bulgaristan (Bağımsızlık Dönemi)", TDV İslâm Ansiklopedisi, Vol. 6, İstanbul 1992, pp. 399-401.

Memişoğlu, Hüseyin, Bulgaristan ve Bulgaristan Türk Azınlı Sorunu, TTK, Ankara 1992.

Oye, David Schimmelpenninck van der, "Russo-Turkish War (1877-1878)", The Encyclopedia of War, Ed. Gordon Martel, 2011, pp. 1-4.

Pakalın, Mehmet Zeki, Sicill-i Osmanî Zeyli, II, TTK, Ankara 2008.

Parmaksız- İgüs, Esma;Bolel Koç, Pınar, "Arşiv, Kadın, Kimlik: Msgsü Resim Heykel Müzesi Arşivinden Leyla Turgut Terekesi", "Women's Memory: The Problem of Sources" 20th Anniversary Symposium of the Women's Library and Information Centre Foundation 17-19 April 2009, İstanbul 2009, pp. 147-151.

Petrovich, Michael Boro, The Emergence of Russian Panslavism 1856-1870, Columbia University Press, New York 1958.

Rodoplu Yıldırım, Fatma, "Bulgar Milli Uyanışı Ve Bulgar Milliyetçiliğinin Özellikleri”, Milliyetçilik Araştırmalan Dergisi, 2/1, 2020, pp. 85-104.

Saatçi, Meltem Begüm, "II. Meşrutiyet Öncesi Makedonya Sorununda "Bulgar" Rolü”, Uluslararası Osmanh ve Cumhuriyet Dönemi Türk Bulgar İlişkileri Sempozyumu, 1113 Mayis 2005 Eskişehir - Türkiye Bildiriler Kitabı, Mayıs 2005, pp. 115-127.

Sancaktar, Caner, "Balkanlar'da Osmanlı Hakimiyeti ve Siyasal Mirası", Ege Stratejik Arastırmalar Dergisi, 2/2, 2011, pp. 27-47. 
Sarınay, Yusuf, “Osmanlı Devleti’nin Bulgaristan’ın Bağımsızlığını Tanıması ve Türk-Bulgar. İlişkilerinin Gelişmesi (1908-1914)", Uluslararası Osmanh ve Cumhurivet Dönemi Türk Bulgar İliskileri Sempozyumu, 11-13 Mayis 2005 Eskişehir-Türkiye Bildiriler Kitabı, Mayıs 2005, pp. 133-137.

Serbestoğlu, İbrahim, Osmanl Kimdir? Osmanl Devleti'nde Tabiiyet Sorunu, Yeditepe Yayınevi, İstanbul 2014.

Serbestoğlu, İbrahim, "Balkan Devletlerindeki Müslümanların Tabiiyeti (18301930)", Mübadele, Şen Gittikङ Yash Döndük, Samsun 2011, pp. 129-134.

Seyfeli, Canan, "Osmanlı Devlet Salnamelerinde Bulgar Eksarhlığı ve Bulgar Katolikler (1847-1918)", Ankara Üniversitesi. Ilahiyat Fakültesi Dergisi, 52/2, 2011, pp. 157-190.

Şimşir, Bilal N., Bulgaristan Türkleri (1878-1985), Bilgi Yayınevi, Ankara 1986.

Tokay, Gül, "A Reassessment of the Macedonian Question, 1878-1908,", in Hakan Yavuz and Peter Sluglett (ed.), War and Diplomacy: The Russo-Turkish War of 1877-1978 and the Treaty of Berlin, Utah University Press, Salt Lake City 2011, pp. 261-264.

Tokay, Gül, Makedonya Sorunu: Fön Türk İtilalinin Kökenleri, 1903-1908, AFA Yayınları, Istanbul 1996.

Tokay, Ahsene Gul, "Macedonian Reforms and Muslim Opposition during Hamidian Era 1878-1908", Islam and Christian-Muslim Relations, 14/1, 2003, pp. 5565.

Tokay, A. Gül, "Osmanl-Bulgar İlişkileri (1878-1908)", Osmanl, Vol. 2, Yeni Türkiye Yayınları, Ankara 1999, pp. 319-328.

Turan, Ömer, "Bulgaristan'da Türklere ve Müslümanlara Yapılan Mezâlim", Uluslararasi Suçlar ve Tarih Dergisi, No. 1, 2006, pp. 89-101.

Turan, Ömer, The Turkish Minority in Bulgaria (1878-1908), TTK, Ankara 1998.

Türkgeldi, Ali Fuat, Görüp İsittiklerim, TTK, Ankara 1987.

Tzaneva, Elya, Ethnosymbolism and the Dynamics of Identity, Cambridge Scholars Publishing, 2015.

Ünal, Hasan, "Ottoman Policy during the Bulgarian Independence Crisis, 19089: Ottoman Empire and Bulgaria at the Outset of the Young Turk Revolution", Middle Eastern Studies, 34/4, 1998, pp. 135-176. 
Üre, Pinar, "Immediate Effects of the 1877-1878 Russo-Ottoman War on the Muslims of Bulgaria", History Studies, Fournal of the University of Limerick History Society, 13, 2012, pp.153-170.

Vatansaver, Erhan, Bulgar Milliyetçiliğinin Doğuşu ve Bulgaristan'm Bă̆ımsızlı̆̆ı (18411908), (Unpublished Ph.D. Thesis), Trakya University, Intitute of Social Sciences Department of History, Edirne 2019.

Yakut, Kemal, Bayrak (Ferlibaş), Meral, “Osmanlı'dan Cumhuriyet'e Bulgaristan Müftülerinin Statüsü (1878-1929), Uluslararası Osmanl ve Cumhuriyet Dönemi Türk Bulgar Illiskileri Sempozyumu, 11-13 Mayıs 2005 Eskişehir - Türkiye Bildiriler Kitabl, Mayıs 2005, pp. 335-346.

Yıldırım, Bülent, Bulgaristan'daki Ermeni Komitelerinin Osmanh Devleti Aleyhine Faaliyetleri (1890-1918), TTK, Ankara 2014.

Yıldız, İsmail, Osmanh Devleti'nin Son Dönemlerinde Bulgaristan'daki Bağgmsızhk Faaliyetleri (1878-1908), (Unpublished Master Thesis), Gazi University, Institute of Social Sciences Department of History, Ankara 2008. 


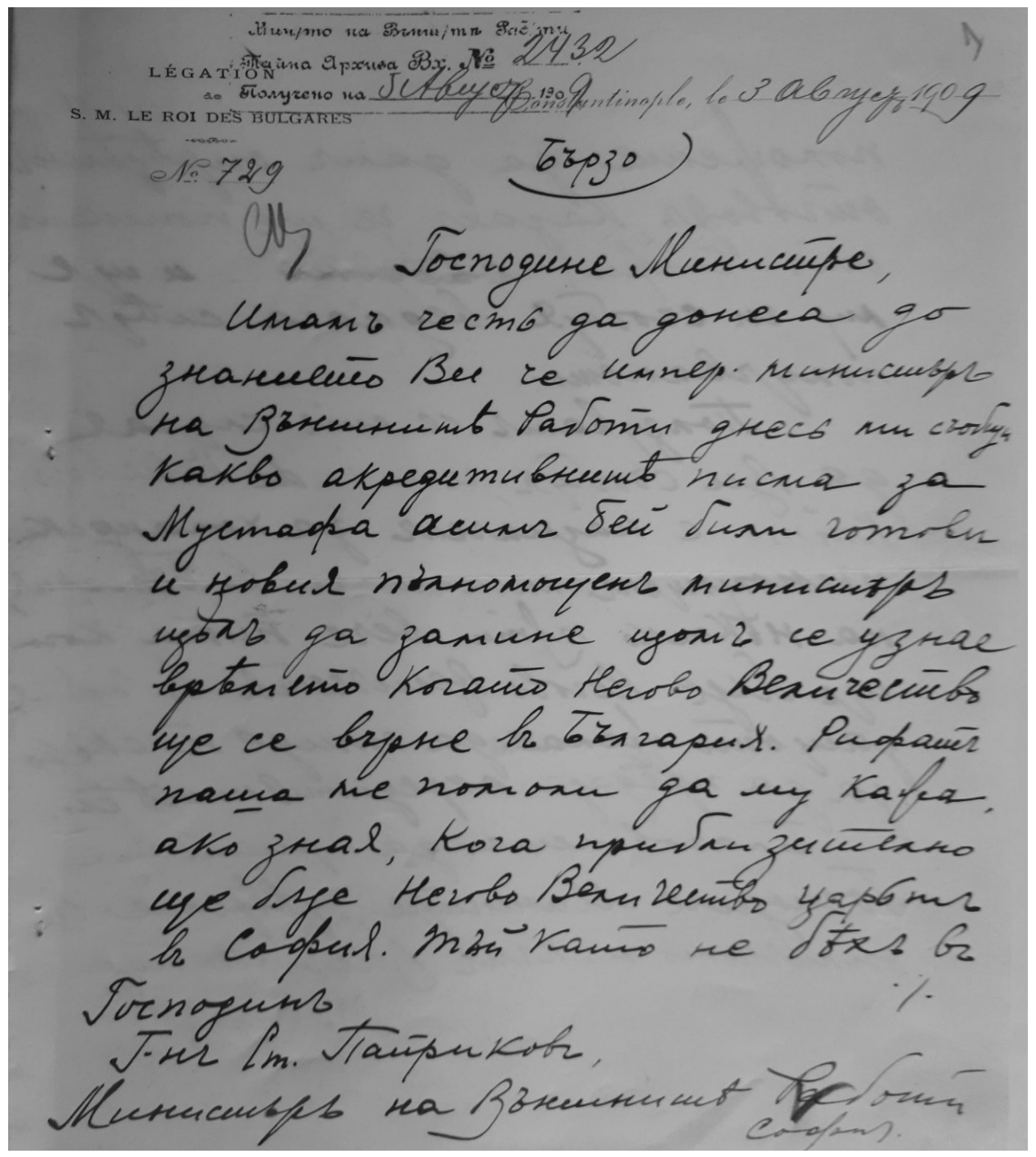

Appendix 1: About Mustafa Asım Bey's credentials

Source: Bulgaria National Archive, fund 176K, archival reference book 14, archival unit 936, nu.2432. 


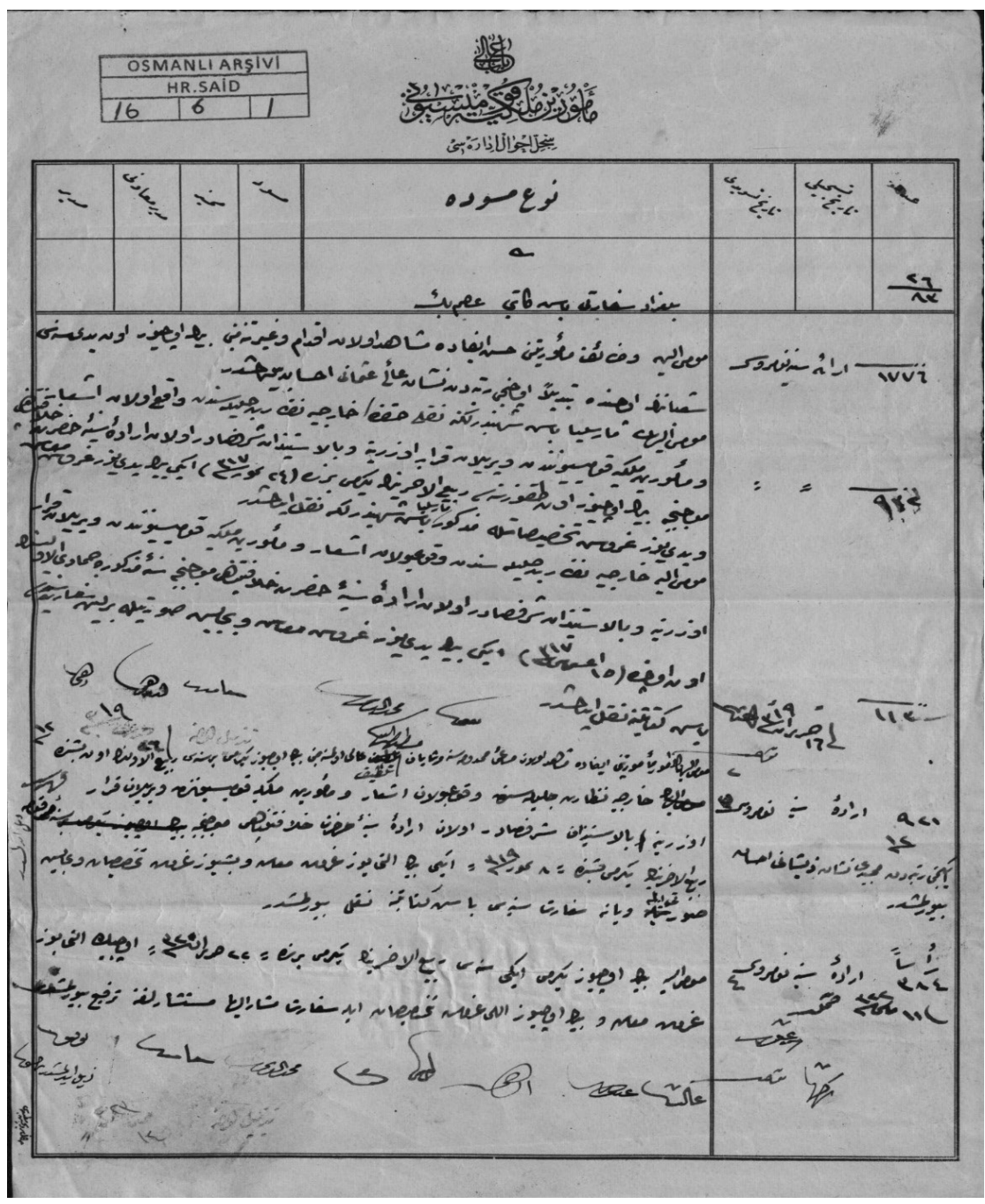

Appendix 2: Biography of Mustafa Asim Bey

Source: BOA. HR.SAID. 16/ 